The Life of Benjamin Franklin volume two 


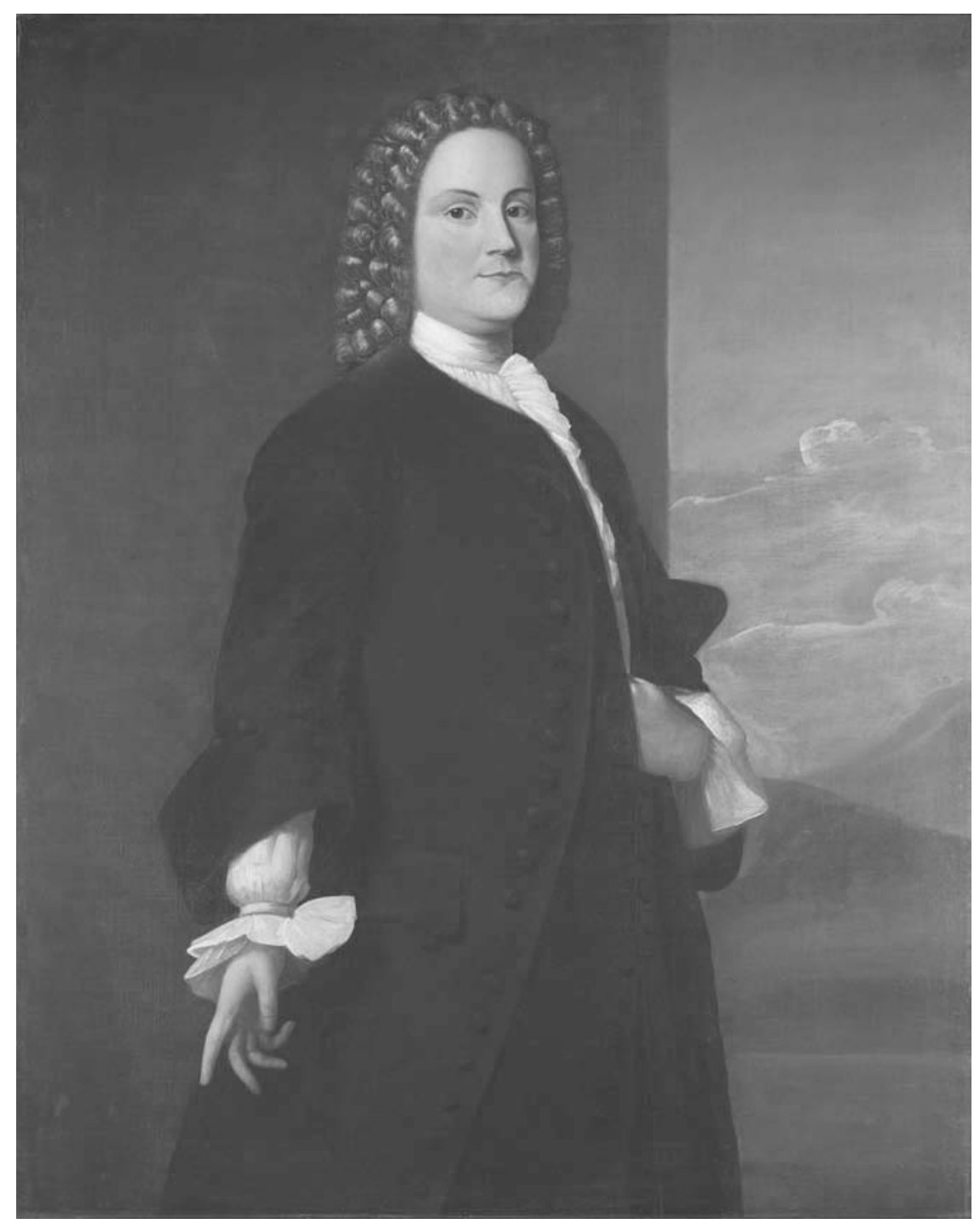




\title{
The Life of
}

Benjamin Franklin

\author{
VOLUME TWO \\ $\sim$
}

\section{Printer and Publisber \\ 1730-1747}

\author{
J. A. Leo Lemay
}

\section{PENN}

University of Pennsylvania Press Philadelphia 
Copyright (C) 2006 University of Pennsylvania Press

All rights reserved

Printed in the United States of America on acid-free paper

$\begin{array}{lllllllll}10 & 9 & 8 & 7 & 6 & 5 & 4 & 3 & 2\end{array}$

Published by

University of Pennsylvania Press

Philadelphia, Pennsylvania 19104-4112

Library of Congress Cataloging-in-Publication Data

Lemay, J. A. Leo (Joseph A. Leo), 1935-

The life of Benjamin Franklin / J. A. Leo Lemay.

p. $\mathrm{cm}$.

Includes bibliographical references and index.

Contents: v. 1. Journalist, 1706-1730-v. 2. Printer and publisher, 1730-1747

ISBN 0-8122-3854-o (v. 1 : acid-free paper). - ISBN 0-8122-3855-9 (v. 2 : acid-free paper)

1. Franklin, Benjamin, 1706-179o. 2. Statesmen-United States-Biography.

3. Scientists-United States-Biography. 4. Inventors-United States-Biography. 5. Printers-United States-Biography. I. Title.

E302.6.F8L424 2005

973.3' $92-\mathrm{dc} 22$

[B]

2004063130

Frontispiece: Benjamin Franklin (1745 or 1746) by Robert Feke. Franklin's older brother John (1690-1756) commissioned the first portrait of Franklin, and he displayed it as a companion piece to his own portrait in his Boston home. Franklin probably chose how to present himself. His wig is brown, comparatively short and simple, and the coat and pants are plain. A gentleman or a professional man would typically be portrayed wearing a more elaborate, longer, white wig and a more ornamental jacket. The portrait suggests that the subject is a successful tradesman, a member of the "middling sort." Courtesy, Harvard University Portrait Collections, bequest of Dr. John Collins Warren, 1856.

Endpapers: Map of Franklin's Philadelphia, with key places of interest indicated. Reprinted from The Papers of Benjamin Franklin, ed. Leonard W. Labaree et al. (New Haven, Conn.: Yale University Press, 1959-), vol. 2, facing p. 456. Courtesy, Ellen Cohn. 
The biography as a whole is dedicated to

Ann C. Lemay, John C. Lemay, Lee C. Lemay, and Kate C. Lemay.

This volume is dedicated to a group of friends who were members of the Natural History Society of Maryland, 1947-57, especially Romeo Mansueti, John E. Cooper, Jack Delaney, Henry C. Eichhorn, Jr., Edmund B. Fladung, Joseph Gentile, John D. Glaser, Harold D. Levy, Anthony G. Marsiglia, Carl Pfeiffer, James B. Toland, and Manfred Wasserman. 
This page intentionally left blank 